\title{
Timing of leaf removal modifies chemical and phenolic composition of Sauvignon Blanc wine
}

\author{
Douglas André Wurz ${ }^{1, a}$, Betina Pereira de Bem ${ }^{1}$, Ricardo Allebrandt ${ }^{1}$, José Luiz Marcon Filho ${ }^{1}$, \\ Alberto Fontanella Brighenti ${ }^{2}$, Marcus Outemane ${ }^{1}$, Leo Rufato ${ }^{1}$, and Aike Anneliese Kretzschmar ${ }^{1}$
${ }^{1}$ Santa Catarina State University (UDESC), College of Agriculture and Life Science, Av. Luiz de Camões, 2090, CEP 88520-000, Lages, SC, Brazil
${ }^{2}$ Santa Catarina State Agricultural Research and Rural Extension Agency (EPAGRI), João Araújo Lima Street, 102, CEP 88520-000, \\ São Joaquim, SC, Brazil
}

\begin{abstract}
The objective of this work was to evaluate the effect of different defoliation times on the chemical and phenolic composition of Sauvignon Blanc wine in high altitude regions of Santa Catarina - Brazil. The experiment was conducted in the 2015 and 2016 seasons, in a vineyard located in the city of São Joaquim - Santa Catarina State. The defoliation was carried out during phenological stages: full bloom, berries pepper-corn size, pea-sized berries, veraison, 15 days after veraison and control without leaf removal. During harvest, severity of Botrytis cinerea was assessed by visual evaluation through a diagrammatic scale. For the wine samples from each season, total acidity (meq $\left.\mathrm{L}^{-1}\right), \mathrm{pH}$, total polyphenol content $\left(\mathrm{mg} \mathrm{L}^{-1}\right.$ of gallic acid) and color (Abs 420nm) were performed. For the wines of the 2015 harvest, phenolic compounds were analyzed: gallic acid, catechin, vanillic acid, P-coumaric acid and rutin. The chemical composition of Sauvignon Blanc wine was affected as a result of leaf removal timing, defoliation carried out in full bloom, berries pepper-corn size and pea-sized berries reduced total acidity and increased $\mathrm{pH}$ of the wines in both seasons. For wine color, in both seasons, it was found a greater yellow coloration in wines originated from grapes where the plants were not defoliated. The increase of yellow coloration is due to the oxidation of catechins and epicatechins, which is related to the increase of botrytis bunch rot. In the 2015 season there were no influence of leaf removal timing in total polyphenols, however, in the 2016, the defoliation performed in full bloom resulted in lower polyphenols contents. Wines from non-defoliated plants presented higher values of catechin, rutin, P-coumaric acid and gallic acid, related to yellow coloration of wines and greater susceptibility to darkening and oxidation. For vanillic acid, wines from non-defoliated plants have the lowest values, this compound is important in wine preservation. Leaf removal is an important management technique in high altitude regions of Santa Catarina - Brazil, it improves wine chemical composition, and if carried out during the stages of full bloom, pepper corn berries and pea-sized berries can reduce the severity of Botrytis bunch rot; and avoid the formation of phenolic compounds related to the processes of oxidation and darkening.
\end{abstract}

\section{Introduction}

Highland regions of Santa Catarina State, Brazil, have been acquiring great importance due to the high potential for wine production from Vitis vinifera L. cultivars [1-3]. Located between latitudes $26^{\circ}$ and $28^{\circ} \mathrm{S}$ and altitudes between $950 \mathrm{~m}$ and $1400 \mathrm{~m}$ a.s.l. the knowledge and characterization of this region shows potential to produce quality wines, but due to highlands of Santa Catarina State are being in an emergent wine grown region fundamental investigations into vineyard practices are necessary [4].

In modern viticulture, the management of vine growth plays a fundamental role in the grapevine development, and it is widely recognized as a determining factor in the composition of wines [5]. Management of vine growth for wine grape cultivation have been developed to optimize sunlight interception, photosynthetic capacity and canopy microclimate for the purpose of improve fruit production

a e-mail: douglaswurz@hotmail.com and wine quality, especially in vigorous varieties with dense canopies [6].

Basal leaf removal may be employed to improve air and light exposure around clusters, as well as to open access to disease- and pest-control chemicals [7]. It is a vineyard practice carried out in all wine-growing regions, which is usually applied between the setting and véraison phenological stages of the grapevine [8,9]. However, leaf removal before setting has become more common [10]. An effect generally associated with basal leaf is a reduce incidence of bunch rot [11]. Besides that, anthocyanin levels and skin color generally are significantly enhanced, particularly in cool climate. Basal leaf removal may increase sugar and polyphenols, improving grape quality at harvest [12]. Whereas, an effect generally associated with basal leaf removal is a drop in titratable acidity $[12,13]$.

To improve our understanding about vineyard practices, the present study aims to investigate the effect of different leaf removal time on the botrytis bunch rot disease development and chemical-phenolic composition 
Table 1. Chemical parameters (titratable acidity, $\mathrm{pH}$ and color) of Sauvignon Blanc wines under effect of different leaf removal times in the high-altitude regions of southern Brazil. Vintages 2015 and 2016.

\begin{tabular}{|c|c|c|c|c|c|c|}
\hline \multirow{2}{*}{ Leaf Removal Time } & \multicolumn{2}{|c|}{$\begin{array}{c}\text { Acidity } \\
\left(\mathbf{m e q ~ L}^{-1}\right)\end{array}$} & \multicolumn{2}{c|}{ pH } & \multicolumn{2}{c|}{$\begin{array}{c}\text { Color } \\
\text { (Abs 420 nm) }\end{array}$} \\
\cline { 2 - 7 } & $\mathbf{2 0 1 5}$ & $\mathbf{2 0 1 6}$ & $\mathbf{2 0 1 5}$ & $\mathbf{2 0 1 6}$ & $\mathbf{2 0 1 5}$ & $\mathbf{2 0 1 6}$ \\
\hline Full bloom & $132.5 \mathrm{a}$ & $115.8 \mathrm{a}$ & $3.00 \mathrm{~d}$ & $3.01 \mathrm{~b}$ & $0.06 \mathrm{a}$ & $0.05 \mathrm{a}$ \\
\hline Berries pepper-corn size & $131.7 \mathrm{a}$ & $113.6 \mathrm{a}$ & $2.88 \mathrm{~b}$ & $2.98 \mathrm{~b}$ & $0.06 \mathrm{a}$ & $0.06 \mathrm{~b}$ \\
\hline Berries pea size & $136.6 \mathrm{~b}$ & $114.3 \mathrm{a}$ & $2.88 \mathrm{~b}$ & $2.99 \mathrm{~b}$ & $0.05 \mathrm{a}$ & $0.06 \mathrm{~b}$ \\
\hline Veraison & $145.2 \mathrm{c}$ & $124.4 \mathrm{~b}$ & $2.85 \mathrm{a}$ & $2.90 \mathrm{a}$ & $0.05 \mathrm{a}$ & $0.07 \mathrm{~b}$ \\
\hline 15 days after veraison & $137.1 \mathrm{~b}$ & $135.6 \mathrm{c}$ & $2.93 \mathrm{c}$ & $2.88 \mathrm{a}$ & $0.06 \mathrm{a}$ & $0.10 \mathrm{c}$ \\
\hline Control (no leaf removal) & $157.5 \mathrm{~d}$ & $142.4 \mathrm{c}$ & $2.93 \mathrm{c}$ & $2.86 \mathrm{a}$ & $0.08 \mathrm{~b}$ & $0.10 \mathrm{c}$ \\
\hline CV $(\%)$ & 1.0 & 4.0 & 0.5 & 1.2 & 7.2 & 9.3 \\
\hline
\end{tabular}

* Means followed by different letters in the same column differ by Skott Knott test $(\mathrm{p}<0.05)$.

of Sauvignon Blanc wines in order to guide appropriate management for winemaking in regions $900 \mathrm{~m}$ a.s.l. of Southern Brazil.

\section{Materials and methods}

Experiment was undertaken in a commercial Vitis vinifera L. cv. Sauvignon blanc vineyards located in São Joaquim county (28०17'39" S, 49 55'56" $\mathrm{W}$ and $1.230 \mathrm{~m}$ above sea level), State of Santa Catarina (SC), southern Brazil, during the year 2014-2015 and 2015-2016 growing seasons.

The climate of the region has been classified as "Cool, Cool nights and Humid", Heliothermic Index of 1.714, average annual rainfall of $1.621 \mathrm{~mm}$ and average annual relative humidity of $80 \%$ [14]. Soil type is cambisol, which is characterized as having high clay $\left(492 \mathrm{~g} \mathrm{~kg}^{-1}\right)$ and organic matter $\left(71 \mathrm{~g} \mathrm{~kg}^{-1}\right)$ [15].

Sauvignon Blanc vines (grafted on '1103 Paulsen') were planted in 2004 in a northwest to southeast row orientation, with a $3.0 \mathrm{~m}$ (row) $\times 1.5 \mathrm{~m}$ (vine) spacing. Vines were trained on a vertical shoot position in a double cordon spur-pruning at $1.2 \mathrm{~m}$ height and covered with antihail net.

The treatments consisted of leaf removal at clusterzone in five different phenological stages according to Baillod \& Baggiollini [16] scale: full bloom, berries pepper-corn size, berries pea size, veraison, 15 days after veraison and control (no leaf removal). Leaf removal was performed manually, removing three basal leaves, including leaf opposite to cluster, exposing completely the grapes. Vineyards practices (pruning, shoot topping and control diseases) were maintained as recommended to commercial growers in this region.

During harvest, $60 \mathrm{~kg}$ of grape per treatment was hand-picked to winemaking process. The winemaking was performed in research scale following protocols described by Pszczolkowski \& Lecco et al. [17]

Wine samples were immediately submitted to the following analysis: a. titratable acidity (meq $\left.\mathrm{L}^{-1}\right) ; \mathrm{b}$. $\mathrm{pH}$. These analyses were determined by protocols of OIV [18]; c. Color, determined by the spectrophotometry method with absorbance in $420 \mathrm{~nm}$ wavelength described by Rizzon [19] and d. Total polyphenols ( $\left.\mathrm{mg} \mathrm{L}^{-1}\right)$, determined by the spectrophotometry method described by Singleton and Rossi [20], using the Folin-Ciocalteu reagent, with absorbance in $760 \mathrm{~nm}$ wavelength. Phenolic content was determined using a gallic acid calibration curve.
Table 2. Botrytis bunch rot severity in the Sauvignon Blanc's cluster under effect of different leaf removal times in the highaltitude regions of southern Brazil. Vintages 2015 and 2016.

\begin{tabular}{|c|c|c|}
\hline \multirow{2}{*}{ Leaf removal time } & \multicolumn{2}{|c|}{ Severity (\%) } \\
\cline { 2 - 3 } & $\mathbf{2 0 1 5}$ & $\mathbf{2 0 1 6}$ \\
\hline Full bloom & $7 \mathrm{a}$ & $13 \mathrm{a}$ \\
\hline Berries pepper-corn size & $7 \mathrm{a}$ & $14 \mathrm{a}$ \\
\hline Berries pea size & $19 \mathrm{~b}$ & $21 \mathrm{a}$ \\
\hline Veraison & $32 \mathrm{c}$ & $29 \mathrm{~b}$ \\
\hline 15 days after veraison & $33 \mathrm{c}$ & $35 \mathrm{~b}$ \\
\hline Control (no leaf removal) & $42 \mathrm{~d}$ & $44 \mathrm{~d}$ \\
\hline CV (\%) & 23.9 & 20.7 \\
\hline
\end{tabular}

* Means followed by different letters in the same column differ by Skott Knott test $(\mathrm{p}<0.05)$.

Table 3. Total polyphenol of Sauvignon Blanc wines under effect of different leaf removal times in the high-altitude regions of southern Brazil. Vintages 2015 and 2016.

\begin{tabular}{|c|c|c|}
\hline \multirow{2}{*}{ Leaf removal time } & \multicolumn{2}{|c|}{ Total polyphenol $\left(\mathbf{m g ~ L}^{-\mathbf{1}}\right)$} \\
\cline { 2 - 3 } & $\mathbf{2 0 1 5}$ & $\mathbf{2 0 1 6}$ \\
\hline Full Bloom & $221.3 \mathrm{a}$ & $267.5 \mathrm{a}$ \\
\hline Berries pepper-corn size & $223.3 \mathrm{a}$ & $299.2 \mathrm{~b}$ \\
\hline Berries pea size & $235.6 \mathrm{a}$ & $320.5 \mathrm{~b}$ \\
\hline Veraison & $216.4 \mathrm{a}$ & $314.6 \mathrm{~b}$ \\
\hline 15 days after veraison & $229.6 \mathrm{a}$ & $311.6 \mathrm{~b}$ \\
\hline Control (no leaf removal) & $245.4 \mathrm{a}$ & $321.7 \mathrm{~b}$ \\
\hline CV $(\%)$ & 5.1 & 8.6 \\
\hline
\end{tabular}

* Means followed by different letters in the same column differ by Skott Knott test $(\mathrm{p}<0.05)$.

Individual polyphenols in the wine were determined using high-performance liquid chromatography (UVHPLC), as described previously [21]. Wine samples were analyzed in triplicate (two injections from the triplicate bottles).

For the severity evaluation of botrytis bunch rot, the evaluations began at the onset of the first symptom, at intervals of 15 days, under natural infection condition. Thirty clusters per treatment were randomly selected, and the evaluations were carried out through a diagrammatic scale described by Hill et al. [23], based on twelve levels of disease severity: $1,5,10,15,20,30,30,40,50,60,70$, 80 and $90 \%$.

The experimental design was a randomized blocks with four blocks and five vines per plot. Data was analyzed by the F test and Skott Knott's multiple range tests $(\mathrm{p}<0.05)$. 
Table 4. Concentration of polyphenols (Gallic acid, vanillic acid, p-cumaric acid and rutin) obtained by HPLC in the final wines of Sauvignon Blanc under effect of different leaf removal times in the high-altitude regions of southern Brazil. Vintage 2015.

\begin{tabular}{|c|c|c|c|c|c|}
\hline \multirow{2}{*}{ Leaf removal time } & Gallic Acid & Catequin & Vanillic Acid & P-cumaric acid & Rutin \\
\hline & $\left(\mathrm{mg} \mathrm{L}^{-1}\right)$ & $\left(\mathrm{mg} \mathrm{L}^{-1}\right)$ & $\left(\mathrm{mg} \mathrm{L}^{-1}\right)$ & $\left(\mathrm{mg} \mathrm{L}^{-1}\right)$ & $\left(\mathbf{m g ~ L ^ { - 1 }}\right)$ \\
\hline Full bloom & $9.23 \mathrm{~b}$ & $4.96 \mathrm{~b}$ & $0.67 \mathrm{~d}$ & $0.32 \mathrm{c}$ & $0.84 \mathrm{~b}$ \\
\hline Berries pepper-corn size & $7.05 \mathrm{a}$ & $4.64 \mathrm{~b}$ & $0.54 \mathrm{c}$ & $0.12 \mathrm{a}$ & $0.49 \mathrm{a}$ \\
\hline Berries pea size & $5.88 \mathrm{a}$ & $4.71 \mathrm{~b}$ & $0.53 \mathrm{c}$ & $0.09 \mathrm{a}$ & $0.46 \mathrm{a}$ \\
\hline Veraison & $6.34 \mathrm{a}$ & $4.38 \mathrm{~b}$ & $0.42 \mathrm{~b}$ & $0.19 \mathrm{~b}$ & $0.87 \mathrm{~b}$ \\
\hline 15 days after veraison & $8.88 \mathrm{~b}$ & $4.57 \mathrm{~b}$ & $0.44 \mathrm{~b}$ & $0.16 \mathrm{~b}$ & $0.49 \mathrm{a}$ \\
\hline Control (no leaf removal) & $8.77 \mathrm{~b}$ & $6.07 \mathrm{a}$ & $0.32 \mathrm{a}$ & $0.31 \mathrm{c}$ & $1.22 \mathrm{c}$ \\
\hline CV (\%) & 10.1 & 10.8 & 13.2 & 10.4 & 9.2 \\
\hline
\end{tabular}

*Means followed by different letters in the same column differ by Skott Knott test $(\mathrm{p}<0.05)$.

\section{Results and discussion}

We observed influence of leaf removal timing on the total acidity, $\mathrm{pH}$ and color of Sauvignon Blanc wines (Table 1). At both harvests, leaf removal carried out until berries pepper-corn size phenological stages resulted wines with the lowest values of total acidity, while wines from plants without leaf removal show the highest total titratable acidity. Early leaf removal associated with high solar radiation provides a reduction in berries acidity due to the greater degradation of malic acid $[24,25]$.

For $\mathrm{pH}$ of the wine, it was observed that earlier leaf removal, before véraison, showed elevation of $\mathrm{pH}$ (Table 1). As reported by other authors [24-26], leaf removal resulting in an increase in $\mathrm{pH}$, as a consequence of direct exposure of the cluster to solar radiation.

To color (Abs $420 \mathrm{~nm}$ ) was observed higher values in wines from non-defoliated vines at both vintages (Table 1). This behavior could be related to more botrytis bunch rot severity observed in the Sauvignon Blanc vines without leaf removal (Table 2). Similar results were observed by Meneguzzo et al. [27] who verified that color index of Gewurztraminer wines increased with the increase of the bunch rot.

In the Sauvignon Blanc clusters, it was observed that early leaf removal carried out up to berries pea size phenological stage resulted a reduction in the severity of botrytis bunch rot, while a significant increase in the severity of botrytis was observed in plants not submitted to leaf removal management (Table 2). Viticulture has a need to acquire more sustainable forms of cultivation (3), and consequently reducing the use of chemical methods of disease control. Vineyards practice that result in greater sun exposure and ventilation in the cluster zone such leaf removal are efficient tools in disease control in grapevine cluster $[11,28]$.

For the concentration of total polyphenols in wines, no difference was observed among leaf removal treatments, except for the defoliation performed at full bloom phenologial stage in the 2016 harvest (Table 3). Although there was no influence of the leaf removal time on the total polyphenol concentration in the 2015 vintage, it was verified that leaf removal influenced the concentration of individual polyphenols (Table 4).

Wines from vines with leaf removal performed at full bloom, 15 days after véraison and control show higher values of gallic acid (Table 3). Also it was observed that plants with no leaf removal resulted in wines with the highest content of catechin and rutin, and lowest value for vanillic acid (Table 3). In white wines the catechins are the main flavonoids. These compounds are responsible for browning and some bitterness in wines $[29,30]$.

Vine not submitted to the leaf removal management as well as the leaf removal performed in the full bloom phenological stage present the highest contents of the Pcoumaric acid (Table 3). The importance of these acids are related to phenomena of oxidative browning that the musts or white wines can suffer. These compounds, rich in hydroxyl groups, are the first phenolic substances to be oxidized by the phenoloxidase enzymes in the respective quinones. These quinones are involved in reactions that lead to the appearance of compounds, with colorings ranging from yellow to brown, in musts.

According to the results observed in this study, higher values of polyphenol were found in wines from vines not submitted to the leaf removal management; however, such compounds are responsible for phenomena of darkening of white wines, oxidation, bitterness, thus having a negative effect to the wine quality.

A thorough knowledge of the various polyphenolic structures present in the grape and the mechanisms of its evolution during winemaking is an indispensable basis to development of the technological processes adapted both the vineyard and the winery [31]. Therefore, the results observed in this work demonstrate that the management of basal leaf removal must be performed according to winery standards due its impact to oenological performance of grapes.

\section{Conclusion}

Leaf removal is an important vineyard practice in high altitude regions of Santa Catarina - Brazil because it improves the chemical composition of wine and if it was carried out until berries pea size phonological stage can reduce the severity of botrytis bunch rot, besides avoid the formation of phenolic compounds related to the processes of oxidation and darkening.

\section{References}

[1] E. F. Gris, V.M. Burin, E. Brighenti, H. Vieira and M.T. Bordignon-Luiz. Phenology and ripening of Vitis vinifera L. grape varieties in São Joaquim, southern Brazil: a new South American wine growing region. Cie. Inv. Agr. 37, 61-75 (2010)

[2] L.I. Malinovski, L.J. Welter, A.F. Brighenti, H.J. Vieira, M.P. Guerra and A.L. Da Silva, A.L. 2012. Highlands of Santa Catarina/Brazil: a region with 
high potential for wine production. Acta Hort. 931, 433-440 (2012)

[3] A.F. Brighenti, E. Brighenti, V. Bonin, and L. Rufato. Caracterização fenológica e exigência térmica de diferentes variedades de uvas viníferas em São Joaquim, Santa Catarina - Brasil. Ciên. Rural. 43, 1162-1167 (2013)

[4] J.L. Marcon Filho. Sistemas de condução na produção de uvas viníferas e composição química e aromática de vinhos em região de altitude de Santa Catarina (Thesis, Lages, 188, 2016)

[5] M. Bogicevic, V. Maras, M. Mugosa, V. Kodzulovic, J. Raicevic, S. Sucur, O. Faila. The effects of early leaf removal and cluster thinning treatments on berry growth and grape composition in cultivars Vranac and Cabernet Sauvignon. Chemical and Biological Technologies in Agriculture 2, 1-8 (2015)

[6] S. Jogaiah, D.P. Oulkar, A.N. Vijapure, S.R. Maske, A.K. Sharma, R.G. Somkuvar. Influence of canopy management practices on fruit composition of wine grape cultivars grown in semi-arid tropical region of India. African Journal of Agricultural Research 8, 3462-3472 (2013)

[7] A. Miele, F. Mandelli. Manejo dossel vegetativo e seu efeito nos componentes de produção da videira Merlot. Revista Brasileira de Fruticultura 34, 964-973 (2012)

[8] D.C. Percival, K.H. Fisher, J.A. Sullivan. Use of fruit zone leaf removal with Vitis vinifera L. cv Riesling grapevines. II. Effect on fruit composition, yeld, and occurrence of bunch rot (Botrytis cinerea Pers.:Fr). American Journal of Enology and Viticulture 45, 133-140 (1994)

[9] M.P. Diago, M. Vilanova, J. Tardaguila. Effects of timing of manual and mechanical early defoliation on the aroma of Vitis vinifera L. Tempranillo wine. American Journal of Enology and Viticulture 61, 382-391 (2010)

[10] B.L. Komm, M.M. Moyer. Effect of early fruitzone leaf removal on canopy development and fruit quality in Riesling and Sauvignon Blanc. American Journal of Enology nd Viticulture 66, 424-434 (2015)

[11] D. Molitor, M. Behr, S. Fischer, L. Hoffamann, D. Evers. Timing of cluster-zone leaf removal and its impact on canopy morphology, cluster architecture and bunch rot susceptibility of grapes. Journal International des Sciences de la Vigne et du Vin 45, 149-159 (2011)

[12] S. Poni, L. Casalini, F. Bernizzoni, S. Civardi, C. Intrieri. Effects of early defoliation on shoot photosynthesis, yield components, and grape quality. American Journal of enology and Viticulture 57, 397-407 (2006)

[13] M.P. Diago, Z.N. Ayestarán, A. Garrido, J. Tardaguila. Phenolic composition of Tempranillo wines following early defoliation of the vines. Journal Science Food Agriculture 92, 925-934 (2012)

[14] J. Tonietto, A. Carbonneau. A multicriteria climatic classification system for grape-growing worlwide. Agricultural and Forest Meteorology 124, 81-97 (2004)

[15] SOLOS do Estado de Santa Catarina (Rio de Janeiro, Embrapa Solos, 726, 2004)
[16] M. Baillod, M. Baggiolini. Les stades repéres de la vigne. Revue suisse de viticulture arboriculture horticulture 25, 7-9 (1993)

[17] P. Pszczolkowski, C.C. Lecco. Manual de vinificácion: guia práctica para la elaborácion de vinos (Santiago, Universidade Católica do Chile, 2011)

[18] OIV - Organization Internationale de la Vigne et du Vin. Compendium of International Methods of Wine and Must Analysis (OIV, Paris, 2009)

[19] L.A. Rizzon. Metodologia para análise do vinho. (Brasília, Embrapa Iformações Tecnológicas, 120, 2010)

[20] V.L. Singleton, J.A. Rossi. Colorymetry of total phenolics with phosphomolibdic-phosphotungstic acid reagent. Am. J. Enol. Vitic. 16, 144-158 (1965)

[21] E. Cadahía, B. Fernandez de Simon, M. Sanz, P. Poveda, J. Colio. Chemical and chromatic characteristics of Tempranillo, Cabernet Sauvignon and Merlot wines from Do Navarra aged in Spain and French oak barrels. Food Chemistry 115, 639-649 (2009)

[22] G.N. Hill, R.M. Beresford, K.J. Evans. Tools for accurate assessment of botrytis bunch rot (Botrytis cinerea) on wine grapes. New Zealand Plant Protection 63, 174-181 (2010)

[23] D.S. Intrigliolo, E. Llacer, J. Revert, M.D. Esteves, M.D. Clement, D. Palau, I, Gómez. Early defoliation reduces cluster compactness and improves grape composition in Mandó, an autochthonous cultivar of Vitis vinifera form southeastern Spain. Scientia Horticulture 167, 71-75 (2014)

[24] D. Risco, D. Pérez, A. Yeves, J.R. Castel, D.S. Intrigliolo. Early defoliation in a temperate warm and semi-arid Tempranillo vineyard: vine performace and grape composition. Autralian Journal Grape Wine Research 20, 111-122 (2014)

[25] S. Poni, F. Bernizzoni, S. Civardi. The effect of early leaf removal on whole-canopy gas exchange and vine performace of Vitis vinifera L. Sangiovese. Vitis 47, 1-6 (2008)

[26] J. Meneguzzo, L.A. Rizzon, A. Miele, M.A. Ayub. Efeito de Botrytis cinerea na composição do vinho Gewurztraminer. Ciência e Tecnologia Alimentos 26, 527-532 (2006)

[27] D. Molitor, N. Baron, T. Sauerwein, C. André, A. Kicherer, J. Doring, M. Stoll, M. Beyer, L. Hoffmann, D. Evers. Postponing first shoot topping reduces grape cluster compacteness and delays bunch rot epidemic. American Journal of Enology and Viticulture 66, 164-176 (2014)

[28] B.W. Zoecklein, K.C. Fugelsang, B.H. Gump, F.S. Nury. Wine Analisys and production (The Chapman e Hall Enology Library, International Thompson Publishing, 1995)

[29] M.O. Downey. Analysis of tannins in seeds and skins of Shiraz grapes throught berry development. Australian Journal of Grape and Wine Research 9, 15-27 (2003)

[30] V. Cheynier, M. Moutounet, Los compuestos fenólicos. In C. Flanzy. Enología: fundamentos científicos y tecnológicos (Madri, AMV Ediciones, 114-136, 2000) 